Article

\title{
The Potential of Peroxidases Extracted from the Spent Mushroom (Flammulina velutipes) Substrate Significantly Degrade Mycotoxin Deoxynivalenol
}

\author{
Ko-Hua Tso $\left.{ }^{1} \mathbb{(}\right)$, Chompunut Lumsangkul ${ }^{2} \mathbb{D}$, Jyh-Cherng Ju $1,3,4,5, * \mathbb{C}$, Yang-Kwang Fan ${ }^{1, *}$ and Hsin-I Chiang ${ }^{1, *}(\mathbb{D}$ \\ 1 Department of Animal Science, National Chung Hsing University, Taichung 40227, Taiwan; \\ d100037004@mail.nchu.edu.tw \\ 2 Department of Animal and Aquatic Sciences, Faculty of Agriculture, Chiang Mai University, \\ Chiang Mai 50200, Thailand; chompunut.lum@cmu.ac.th \\ 3 Graduate Institute of Biomedical Sciences, China Medical University, Taichung 40402, Taiwan \\ 4 Translational Medicine Research Center, China Medical University Hospital, Taichung 40402, Taiwan \\ 5 Department of Bioinformatics and Medical Engineering, College of Information and Electrical Engineering, \\ Asia University, Taichung 41354, Taiwan \\ * Correspondence: jcju@dragon.nchu.edu.tw (J.-C.J.); ykfan7712@gmail.com (Y.-K.F.); \\ samchiang@nchu.edu.tw (H.-IC.); Tel.: +886-4-2287-0613 (J.-C.J. \& Y.-K.F. \& H.-IC.); \\ Fax: $+886-4-2286-0265$ (J.-C.J. \& Y.-K.F. \& H.-IC.)
}

check for

updates

Citation: Tso, K.-H.; Lumsangkul, C.; Ju, J.-C.; Fan, Y.-K.; Chiang, H.-I The Potential of Peroxidases Extracted from the Spent Mushroom (Flammulina velutipes) Substrate Significantly Degrade Mycotoxin Deoxynivalenol. Toxins 2021, 13, 72. https://doi.org/10.3390/toxins 13010072

Received: 17 November 2020 Accepted: 16 January 2021 Published: 19 January 2021

Publisher's Note: MDPI stays neutral with regard to jurisdictional claims in published maps and institutional affiliations.

Copyright: (c) 2021 by the authors. Licensee MDPI, Basel, Switzerland. This article is an open access article distributed under the terms and conditions of the Creative Commons Attribution (CC BY) license (https:// creativecommons.org/licenses/by/ $4.0 /)$.

\begin{abstract}
Little is known about the degradability of mycotoxin deoxynivalenol (DON) by the spent mushroom substrate (SMS)-derived manganese peroxidase (MnP) and lignin peroxidase (LiP) and its potential. The present study investigated the growth inhibition of Fusarium graminearum KR1 and the degradation of DON by MnP and LiP extracted from SMS. The results from the 7-day treatment period showed that mycelium inhibition of F. graminearum KR1 by MnP and LiP were $23.7 \%$ and $74.7 \%$, respectively. Deoxynivalenol production in the mycelium of $F$. graminearum KR1 was undetectable after treatment with $50 \mathrm{U} / \mathrm{mL}$ of $\mathrm{MnP}$ or LiP for 7 days. $N$-acetyl-D-glucosamine (GlcNAc) content and chitinase activity both increased in the hyphae of $F$. graminearum KR1 after treatment with $\mathrm{MnP}$ and LiP for 1, 3, and $6 \mathrm{~h}$, respectively. At $12 \mathrm{~h}$, only the LiP-treated group had higher chitinase activity and GlcNAc content than those of the control group $(p<0.05)$. However, more than $60 \%$ of DON degradabilities $(0.5 \mathrm{mg} / \mathrm{kg}, 1 \mathrm{~h})$ were observed under various $\mathrm{pH}$ values $(2.5,4.5$, and 6.5) in both $\mathrm{MnP}(50 \mathrm{U} / \mathrm{g})$ and $\mathrm{LiP}(50 \mathrm{U} / \mathrm{g})$ groups, while DON degradability at $1 \mathrm{mg} / \mathrm{kg}$ was $85.5 \%$ after $50 \mathrm{U} / \mathrm{g}$ of LiP treatment for $7 \mathrm{~h}$ in simulated pig gastrointestinal tracts. Similarly, DON degradability at $5 \mathrm{mg} / \mathrm{kg}$ was $67.1 \%$ after LiP treatment for $4.5 \mathrm{~h}$ in simulated poultry gastrointestinal tracts. The present study demonstrated that SMS-extracted peroxidases, particularly LiP, could effectively degrade DON and inhibit the mycelium growth of $F$. graminearum KR1.
\end{abstract}

Keywords: deoxynivalenol; detoxification; Fusarium graminearum; lignin peroxidase; manganese peroxidase

Key Contribution: The spent mushroom substrate of Flammulina velutipes was proved to be a suitable source of deoxynivalenol (DON) degradation enzymes. This study revealed that the crude extract from the cultivation substrate could degrade more than $60 \%$ of DON as well as inhibit the growth of Fusarium graminearum KR1. It can thus serve as an inexpensive, remedial resource for DON contaminated commodities in agriculture.

\section{Introduction}

During harvest, transportation, processing, and storage, feed ingredients are susceptible to fungal infection and contamination by their toxic metabolites-mycotoxins [1]. More than $25 \%$ of worldwide crops are affected by mycotoxins yearly, resulting in a huge financial loss in grain production and causing a threat to the health and life of humans 
and animals [2]. It is known that the 12,13-epoxide ring is the core chemical structure of trichothecenes [3]. Overall, the type B trichothecene deoxynivalenol (DON) is responsible for one of the most severe pollutions in feeds and ingredients. The primary DON toxigenic fungi are Fusarium culmorum and Fusarium graminearum, and the grains subjected to the highest intoxication rates from both fungi are wheat, barley, oats, and corn [4-6]. Also, global climate change has resulted in an increased risk of Fusarium infection in grains, and the worldwide pollution rates of DON in ingredients and feeds have been rising over years, posing a severe threat to animal and human health [7]. It has been reported that DON inhibits the syntheses of protein, DNA, and RNA, as well as the functions of mitochondrial membranes and eukaryotic cell division [8-10]. The DON limitations of the Food and Drug Administration (FDA) in the US and European Union (EU) are 1000 and 200-1750 $\mu \mathrm{g} / \mathrm{kg}$ for human food and animal feed, respectively [11,12].

Strategies for mycotoxin degradation and detoxification include physical, chemical, and biological treatments. Physical treatment do not degrade DON in food and feed products effectively because of its high heat stability and low polarity $[13,14]$. Therefore, DON could remain stable in food and animal feeds for several years at room temperature or even with heat treatment over $100{ }^{\circ} \mathrm{C}$ [13]. In the feed industry, adsorbents such as montmorillonite and yeast cell walls are widely used to absorb mycotoxins in the gastrointestinal tract of animals [15]. However, mycotoxin adsorbents are effective only for high polarity mycotoxins such as aflatoxin $\mathrm{B}_{1}\left(\mathrm{AFB}_{1}\right)$; meanwhile, they may also adsorb feed nutrients, such as amino acids, water-soluble vitamins, and microminerals or likely trace minerals, making these nutrients and micronutrients unavailable for animals $[16,17]$. Chemical and biological degradations of DON may overcome some of these disadvantages because these detoxification methods could ameliorate the toxicity of DON by altering their chemical structures. However, chemical degradations to detoxify mycotoxins are not allowed according to European Union regulations for human food products [18] because they may alter the nutritional compositions of foods and feeds. Unlike chemical degradation, biological detoxification or degradation works through enzymatic degradation and only requires mild reaction conditions close to ambient temperature, which is practically applicable in the food and feed industries [19]. It mainly involves the use of microbes or enzymes to breakdown the toxic chemical structures of mycotoxins to lower the toxicity. Awad et al. [20] demonstrated that DON was degraded into de-epoxy-deoxynivalenol (DOM-1) through de-epoxidation by Eubacterium BBSH 797. For instance, many different bacteria, such as Bacterial LS100 and Bacterial S33, have been isolated from chicken intestinal microbes to convert DON into DOM-1 by de-epoxidation [21]. To date, several microorganisms from various sources such as soils, plants, and lake water, have been reported capable of degrading DON. For instance, the gram-positive bacterium Nocardioides sp. WSN05-2 isolated from wheat could degrade DON to 3-epi-deoxynivalenol by epimerization [22]. It was also found that the cytochrome P450 system in Sphingomonas sp. KSM1, a DON-utilizing bacterium isolated from lake water, was capable of catabolizing DON [23]. Moreover, studies have demonstrated that microorganisms and enzymes could degrade or conjugate with the chemical structure of mycotoxins to reduce their concentration and toxicity [24]. Given the 12,13-epoxide ring being the primary toxic moiety of DON [25], destruction of such key structure can be done by oxidative enzymes that catalyze epoxide ring-opening [26].

It is known that the main extracellular ligninolytic enzymes consist of lignin peroxidase ( $\mathrm{LiP})$, manganese peroxidase $(\mathrm{MnP})$, and laccase. All these ligninolytic peroxidases are involved in lignin biodegradation [27]. Studies showed that the peroxidases of white-rot fungi can oxidize the benzene rings of phenols, non-phenolic aromatics, and amino-aromatic compounds into phenol oxides and hydroxyl free radicals via the epoxide ring-opening reactions [28]. To detoxify $\mathrm{AFB}_{1}, \mathrm{MnP}$ extracted from Phanerochaete sordida YK-624 can remove up to $86 \%$ of its original concentration in $48 \mathrm{~h}$ [29]. Previous studies have suggested that the 8,9-vinyl bond of $\mathrm{AFB}_{1}$ is first oxidized to 8,9-epoxide by $\mathrm{MnP}$, and then being hydrolyzed to $\mathrm{AFB}_{1}-8,9$-dihydrodiol by adding the oxygen atom $[29,30]$. Some 
other studies indicated that MnP of white-rot fungi also effectively degraded DON [30,31]. Besides, not only MnP from white-rot fungi can degrade DON, but also other peroxidases from white-rot fungi or spent mushroom substrate (SMS) have a similar activity [32]. However, no report has detailed the degrading effects of other ligninolytic peroxidases and the antifungal abilities of both MnP and LiP. Therefore, we hypothesized that these peroxidases possess the potential for ring-opening reactions to achieve a real detoxification of DON. In the present study, the growth inhibition of F. graminearum, as well as DON degradability by $\mathrm{MnP}$ and LiP extracted from spent mushroom (Flammulina velutipes) substrate was demonstrated in vitro or in simulated gastrointestinal tracts.

\section{Results}

\subsection{Effects of $M n P$ and LiP on Growth Inhibition of F. graminearum KR1}

The inhibition rates of F. graminearum KR1 mycelium after MnP and LiP treatments for 7 days were $23.7 \%$ and $74.7 \%$, respectively (Table 1 ). However, the MnP treatment promoted (negative value of inhibition rate) slight mycelium growth instead of inhibition in the first 3 days during the experimental period. Beginning on Day 1 and continuing throughout the 7-day incubation period, the inhibition rate of F. graminearum KR1 with LiP treatment was significantly higher than with MnP treatment $(p<0.05)$.

Table 1. Growth inhibition of F. graminearum KR1 by manganese peroxidase (MnP) and lignin peroxidase (LiP) treatments ${ }^{1}$.

\begin{tabular}{|c|c|c|c|c|c|c|c|}
\hline \multirow{2}{*}{ Item } & \multicolumn{7}{|c|}{ Incubation Time, $\mathrm{d}$} \\
\hline & 1 & 2 & 3 & 4 & 5 & 6 & 7 \\
\hline \multicolumn{8}{|c|}{ Diameter, cm } \\
\hline Control $^{1}$ & $2.86 \pm 0.73$ & $4.78 \pm 1.04$ & $5.28 \pm 1.16$ & $6.50 \pm 1.91$ & $6.85 \pm 1.99$ & $7.78 \pm 2.43$ & $9.50 \pm 0.40$ \\
\hline $\mathrm{MnP}$ & $2.90 \pm 0.38$ & $4.70 \pm 0.63$ & $5.28 \pm 0.73$ & $6.12 \pm 1.30$ & $6.34 \pm 1.12$ & $6.62 \pm 1.24$ & $7.28 \pm 1.25$ \\
\hline $\mathrm{LiP}$ & $1.54 \pm 0.36$ & $2.02 \pm 0.53$ & $2.30 \pm 0.40$ & $2.28 \pm 0.12$ & $2.26 \pm 0.60$ & $2.45 \pm 0.54$ & $2.41 \pm 0.29$ \\
\hline \multicolumn{8}{|c|}{ Inhibition rate, $\%$} \\
\hline $\mathrm{MnP}$ & $-5.26 \pm 18.7^{b}$ & $-0.50 \pm 12.3^{b}$ & $-2.11 \pm 12.8^{b}$ & $3.30 \pm 11.3^{b}$ & $3.97 \pm 16.4^{b}$ & $9.44 \pm 23.6^{b}$ & $23.7 \pm 10.2^{b}$ \\
\hline $\mathrm{LiP}$ & $45.2 \pm 8.67^{\mathrm{a}}$ & $57.8 \pm 4.88^{\mathrm{a}}$ & $55.9 \pm 3.54^{\mathrm{a}}$ & $62.1 \pm 11.4^{\mathrm{a}}$ & $66.6 \pm 4.77^{\mathrm{a}}$ & $67.3 \pm 5.10^{a}$ & $74.7 \pm 2.23^{a}$ \\
\hline
\end{tabular}

${ }^{1}$ Control: only potato dextrose agar (PDA); MnP: PDA with $50 \mathrm{U} / \mathrm{mL}$ of manganese peroxidase; LiP: PDA with $50 \mathrm{U} / \mathrm{mL}$ of lignin peroxidase. ${ }^{\mathrm{a}, \mathrm{b}}$ Means for each time point of incubation without the same superscripts differ $(p<0.05)$. Data are expressed as mean $\pm \mathrm{SD}$ $(n=8)$.

\subsection{Influence of MnP and LiP on Cell Wall Hydrolysis and Morphology}

The chitinase activity and N-acetyl-D-glucosamine (GlcNAc) content of the cell wall were examined after the hyphae of F. graminearum KR1 was treated with MnP or LiP at $50 \mathrm{U} / \mathrm{mL}$ for various times (h). After treatment for 1,3 , and $6 \mathrm{~h}$, the chitinase activity and GlcNAc content of the hyphae significantly increased in both treatment groups compared with that in the control group $(p<0.05)$, respectively (Table 2$)$. At $12 \mathrm{~h}$ after treatment, only the LiP-treated group showed higher chitinase activity and GlcNAc content than those of the control treatment. Furthermore, the chitinase activity and GlcNAc content of the LiP-treated hyphae were significantly higher than those of the MnP-treated hyphae $(p<0.05)$, except for those at one hour after treatment (Table 2).

The microscopic examination revealed that LiP treatment at $50 \mathrm{U} / \mathrm{mL}$ for $12 \mathrm{~h}$ induced marked changes in F. graminearum KR1 morphology. In treatments without MnP and LiP, F. graminearum KR1 mycelium demonstrated a dense cytoplasm (Figure 1a). With MnP treatment, some vesicles were visible inside the cell wall (Figure 1b). By contrast, large vesicles were observed inside the cell wall with LiP treatment (Figure 1c). Furthermore, LiP treatment at $50 \mathrm{U} / \mathrm{mL}$ led to significant collapse and breakdown of F. graminearum KR1 hyphae (Figure 1c) $12 \mathrm{~h}$ later.

\subsection{Effects of MnP and LiP on DON Production of F. graminearum KR1}

Figure 2 depicts F. graminearum KR1 culture treated with $\mathrm{MnP}$ and $\mathrm{LiP}$ at $50 \mathrm{U} / \mathrm{mL}$ for 7 days: DON production was not detected in either treatments (the limit of detection was $100 \mu \mathrm{g} / \mathrm{kg}$ ). Furthermore, the control treatment produced $9 \mathrm{mg} / \mathrm{kg}$ of DON. 
Table 2. Chitinase activity in the hyphae and N-acetyl-D-glucosamine (GlcNAc) content of F. graminearum KR1 in Czapek solution agar.

\begin{tabular}{|c|c|c|c|c|}
\hline \multirow{2}{*}{ Item } & \multicolumn{4}{|c|}{ Incubation Time, $h$} \\
\hline & 1 & 3 & 6 & 12 \\
\hline \multicolumn{5}{|c|}{$\begin{array}{l}\text { Chitinase activity, } \\
\text { GlcNAc mg/g } \\
\text { fresh weight/h }\end{array}$} \\
\hline Control $^{1}$ & $0.000 \pm 0.000^{b}$ & $0.012 \pm 0.001^{c}$ & $0.033 \pm 0.001^{c}$ & $0.075 \pm 0.003^{b}$ \\
\hline $\mathrm{MnP}$ & $0.014 \pm 0.002^{\mathrm{a}}$ & $0.066 \pm 0.011^{\mathrm{b}}$ & $0.095 \pm 0.006^{b}$ & $0.117 \pm 0.006^{b}$ \\
\hline $\mathrm{LiP}$ & $0.014 \pm 0.003^{\mathrm{a}}$ & $0.120 \pm 0.015^{\mathrm{a}}$ & $0.179 \pm 0.028^{a}$ & $0.231 \pm 0.043^{a}$ \\
\hline \multicolumn{5}{|c|}{$\begin{array}{l}\text { GlcNAc content, } \\
\text { mg/g fresh weight }\end{array}$} \\
\hline Control $^{1}$ & $0.000 \pm 0.000^{b}$ & $0.011 \pm 0.000^{\mathrm{c}}$ & $0.040 \pm 0.002^{\mathrm{c}}$ & $0.092 \pm 0.002^{b}$ \\
\hline $\mathrm{MnP}$ & $0.020 \pm 0.002^{\mathrm{a}}$ & $0.072 \pm 0.012^{b}$ & $0.084 \pm 0.009^{b}$ & $0.093 \pm 0.017^{b}$ \\
\hline $\mathrm{LiP}$ & $0.019 \pm 0.003^{\mathrm{a}}$ & $0.114 \pm 0.010^{\mathrm{a}}$ & $0.174 \pm 0.012^{\mathrm{a}}$ & $0.286 \pm 0.021^{a}$ \\
\hline
\end{tabular}

${ }^{1}$ Control: only Czapek solution agar (CZ); MnP: CZ with $50 \mathrm{U} / \mathrm{mL}$ of manganese peroxidase; LiP: $\mathrm{CZ}$ with $50 \mathrm{U} / \mathrm{mL}$ of lignin peroxidase. ${ }^{\mathrm{a}-\mathrm{c}}$ Means from each time point of incubation without the same superscripts differ $(p<0.05)$. Data are expressed as mean $\pm \operatorname{SD}(n=3)$.

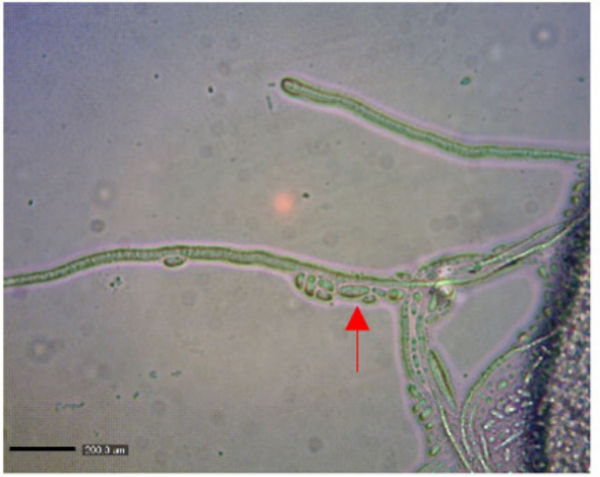

(a)

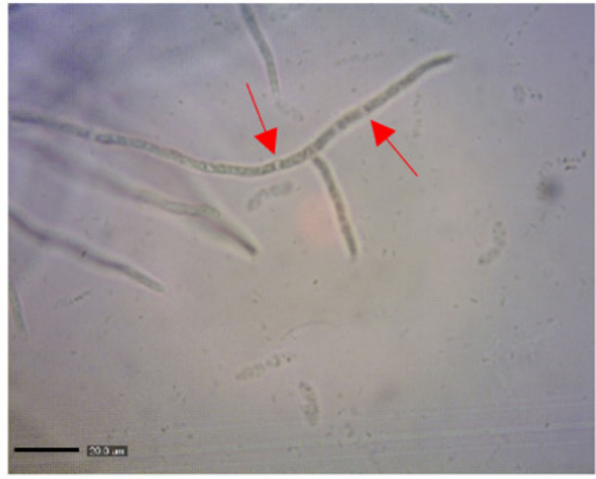

(b)

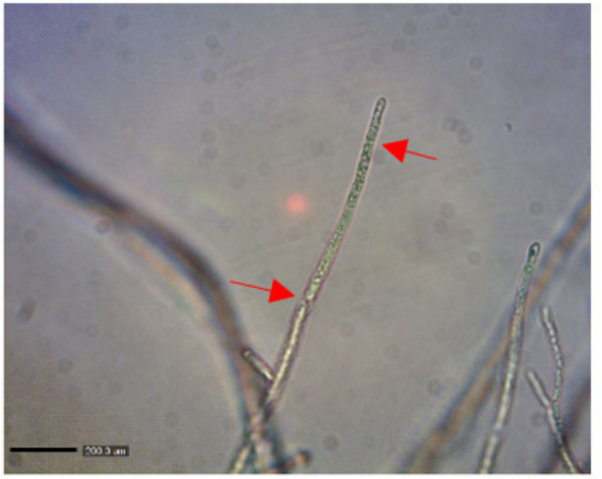

(c)

Figure 1. Morphological observations of F. graminearum KR1 hyphae after treatment with manganese peroxidase (MnP) or lignin peroxidase (LiP) for $12 \mathrm{~h}$. (a) Treatment with the control solution shows intact hyphae with sporulation (arrow). (b) Treatment with $50 \mathrm{U} / \mathrm{mL} \mathrm{MnP}$ shows broken hyphae with points of breakage (arrows). (c) Treatment with $50 \mathrm{U} / \mathrm{mL} \mathrm{LiP}$ shows broken hyphae (arrows) as in the MnP treatment group. Bar $=200 \mu \mathrm{m}$.

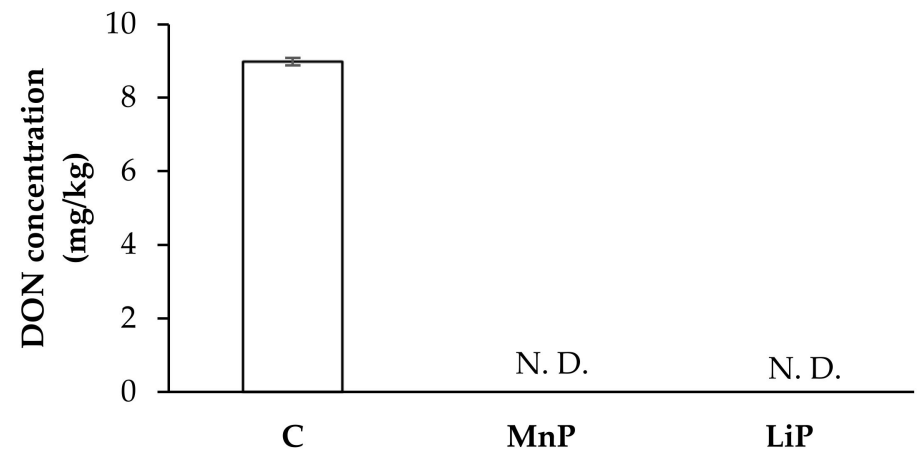

Figure 2. Deoxynivalenol (DON) production by F. graminearum KR1 grown in potato dextrose agar (PDA) for 7 days after SMS-extracted peroxidases treatments $(50 \mathrm{U} / \mathrm{mL})$. C: non-treated control; $\mathrm{MnP}$ : PDA with manganese peroxidase (MnP) treatment; LiP: PDA with lignin peroxidase (LiP) treatment. N. D.: not detectable (the limit of detection is $100 \mu \mathrm{g} / \mathrm{kg}$ for DON). Data are expressed as mean $\pm \mathrm{SD}$ $(n=8)$. 


\subsection{Pre-Test of DON Degradability by MnP and LiP in Artificial Digestive Juices}

Figure 3 shows the residual concentrations of DON degradability treated with $\mathrm{MnP}$ and $\mathrm{LiP}$ in artificial digestive juices at various $\mathrm{pH}(2.5,4.5$, and 6.5) conditions for $1 \mathrm{~h}$. Deoxynivalenol degradabilities of $\mathrm{MnP}$ and $\mathrm{LiP}$ treatments were $63.2 \%$ and $71.7 \%$, respectively, at pH 2.5 in artificial gastric juice (AGJ); under $\mathrm{pH} 4.5$ in AGJ, $67.2 \%$ and $80.3 \%$ of DON degradations, respectively, were observed after MnP and LiP treatments. In artificial intestinal juice (AIJ) at $\mathrm{pH} 6.5$, as much as $75.8 \%$ and $70.7 \%$ of DON degradability, respectively, were observed after $\mathrm{MnP}$ and $\mathrm{LiP}$ treatment. The calculated residual concentrations from the $\mathrm{MnP}$ and $\mathrm{LiP}$ treatment groups respectively were $0.185 \mathrm{mg} / \mathrm{kg}$ and $0.142 \mathrm{mg} / \mathrm{kg}$ under $\mathrm{pH} 2.5$ in AGJ, $0.163 \mathrm{mg} / \mathrm{kg}$, and $0.1 \mathrm{mg} / \mathrm{kg}$ at $\mathrm{pH} 4.5$ in AGJ, and $0.121 \mathrm{mg} / \mathrm{kg}$ and $0.146 \mathrm{mg} / \mathrm{kg}$ at $\mathrm{pH} 6.5 \mathrm{in}$ AIJ. Both the residual concentrations and degradabilities of DON after $\mathrm{MnP}$ and $\mathrm{LiP}$ treatments were significantly lower than those of the control group $(p<0.05)$, but no difference between MnP and LiP treatment groups was observed. Because LiP treatment showed a better antifungal effect than MnP treatment and no significant difference was observed between $\mathrm{MnP}$ and LiP treatments on DON degradability, only the $\mathrm{LiP}$ treatment was selected for the subsequent simulation trials in the digestive tracts of both poultry and pigs.

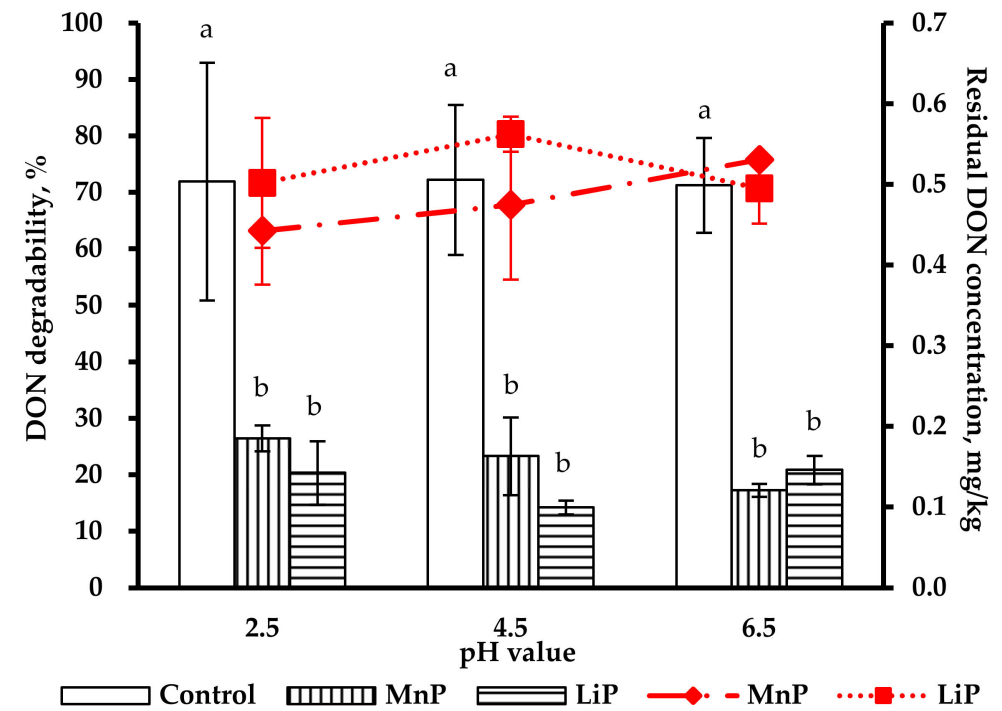

Figure 3. DON degradability (line) and residual concentration (bar) of the Control, $\mathrm{MnP}(50 \mathrm{U} / \mathrm{g})$ and $\mathrm{LiP}(50 \mathrm{U} / \mathrm{g})$ in $\mathrm{AGJ}(\mathrm{pH} 2.5$ and 4.5) and $\mathrm{AIJ}(\mathrm{pH} 6.5)$, respectively, at $1 \mathrm{~h}$ after peroxidase treatments. $\mathrm{a}, \mathrm{b}$ Means for each $\mathrm{pH}$ value without the same superscripts differ $(p<0.05)$. AGJ: Artificial gastric juice; AIJ: Artificial intestinal juice; DON: Deoxynivalenol; MnP: Manganese peroxidase. LiP: Lignin peroxidase. Data are expressed as mean $\pm \mathrm{SD}(n=3)$.

\subsection{Simulation of Pig Gastrointestinal Tracts in DON Degradability by LiP Treatment}

For the simulation of pig stomach conditions $(\mathrm{pH} 2.5)$ for $5 \mathrm{~h}$, the degradability and residual concentration of DON (at $1 \mathrm{mg} / \mathrm{kg}$ ) were $83.3 \%$ and $0.17 \mathrm{mg} / \mathrm{kg}$, respectively, after $\mathrm{LiP}$ treatment (Figure 4). Under the simulated pig small intestine conditions (pH 6.5) for $2 \mathrm{~h}$ (at the 7th $\mathrm{h}$ ), the degradability and residual concentration of DON were $85.1 \%$ and $0.12 \mathrm{mg} / \mathrm{kg}$, respectively after LiP treatment. Beginning from the first hour throughout the whole simulation period (till $7 \mathrm{~h}$ ), DON residual concentrations in the LiP-treated groups were all lower than that in the control group $(p<0.05)$. 


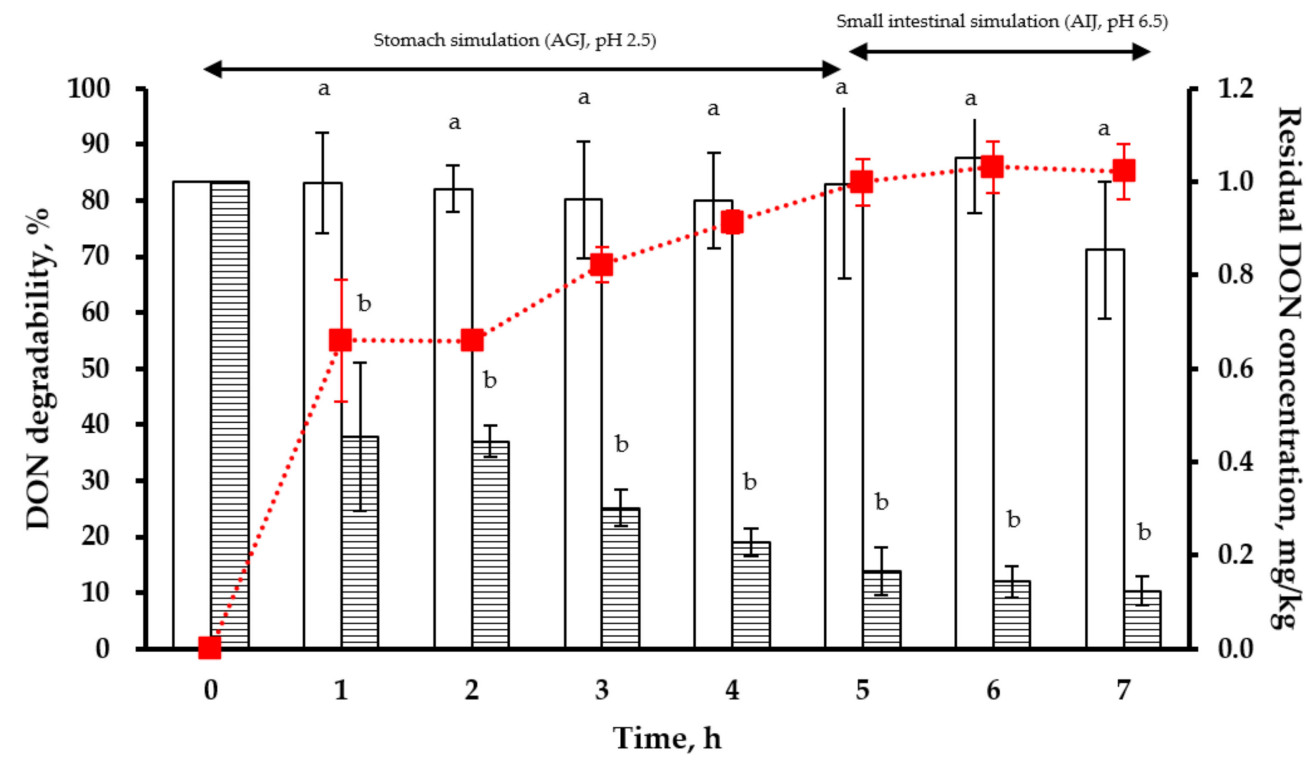

$\square$ Control $\rightleftharpoons \mathrm{LiP} \quad \cdots \cdot \mathrm{e} \cdot \ldots \mathrm{LiP}$

Figure 4. Degradability (line) and residual concentration (bar) of DON after LiP treatment in the simulated pig gastrointestinal tracts $(0$ to $5 \mathrm{~h}$ for stomach simulation and then 6 to $7 \mathrm{~h}$ for small intestine simulation). ${ }^{\mathrm{a}, \mathrm{b}}$ Means for each $\mathrm{pH}$ value without the same superscripts differ $(p<0.05)$. AGJ: Artificial gastric juice; AIJ: Artificial intestinal juice; DON: Deoxynivalenol ( $1 \mathrm{mg} / \mathrm{kg})$; $\mathrm{LiP}$ : Lignin peroxidase $(50 \mathrm{U} / \mathrm{g})$. Data are expressed as mean $\pm \mathrm{SD}(n=3)$.

\subsection{Simulation of Poultry Gastrointestinal Tracts in DON Degradability by LiP Treatment}

Under the simulated poultry crop and glandular stomach condition ( $\mathrm{pH} 4.5$ for $2 \mathrm{~h}$ ), the degradability and residual concentration of DON $(5 \mathrm{mg} / \mathrm{kg})$ after LiP treatment were $39.8 \%$ and $2.8 \mathrm{mg} / \mathrm{kg}$, respectively. In the simulated gizzard conditions ( $\mathrm{pH} 2.5$ for $0.5 \mathrm{~h}$ ), the degradability and residual concentration of DON were $36.5 \%$ and $2.8 \mathrm{mg} / \mathrm{kg}$ (at the 2.5th $\mathrm{h}$ ), respectively. Under the simulated small intestine condition ( $\mathrm{pH} 6.5$ for $2 \mathrm{~h}$ ), the degradability and residual concentration of DON were $67.2 \%$ and $1.6 \mathrm{mg} / \mathrm{kg}$ (at the 4.5 th $\mathrm{h}$ ), respectively (Figure 5). The LiP treatment displayed significant degradability for high DON concentration $(5 \mathrm{mg} / \mathrm{kg})$ throughout the poultry gastrointestinal simulations. The residual concentrations of $\mathrm{DON}$ in the simulated digestive tracts were lower than that in the control group after LiP treatment $(p<0.05)$. 


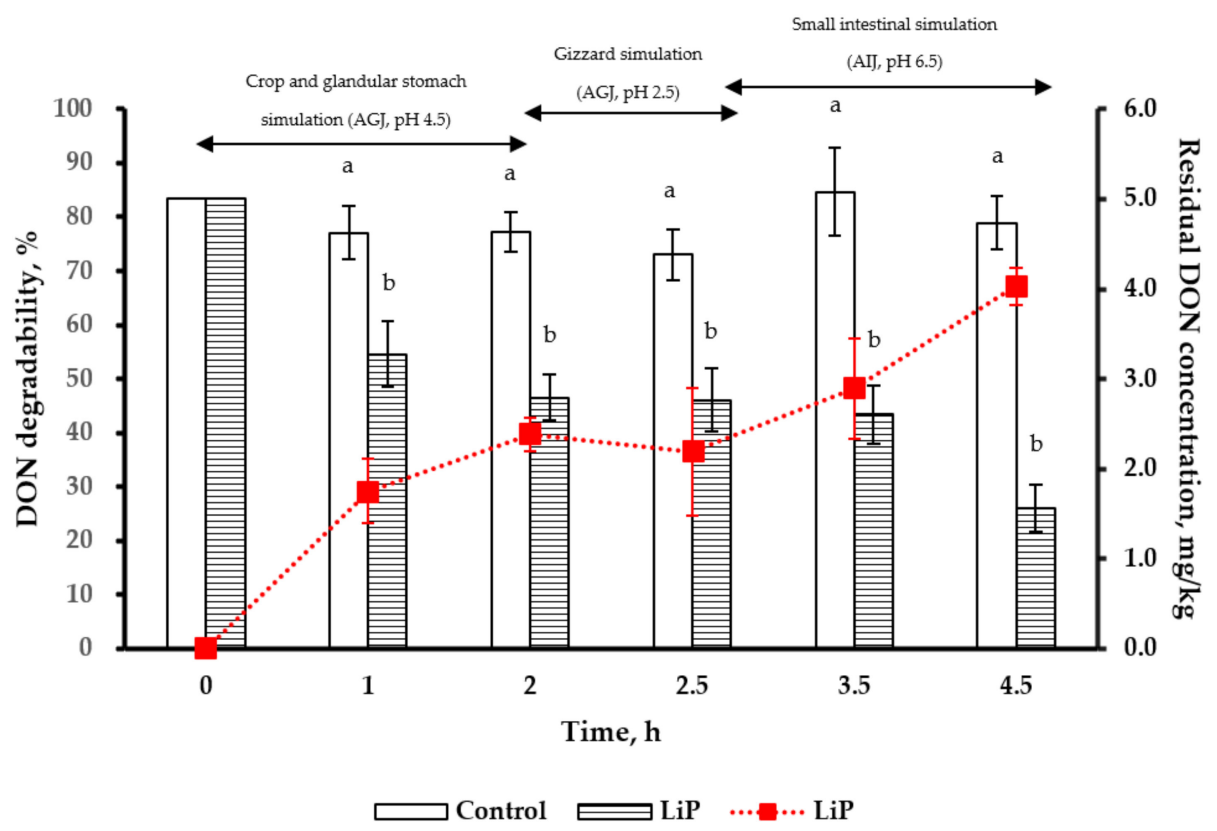

Figure 5. Degradability (line) and residual concentration (bar) of DON in the control and LiP treatment groups under poultry gastrointestinal simulations ( 0 to $2 \mathrm{~h}$ for the crop and glandular stomach, 2 to $2.5 \mathrm{~h}$ for the gizzard, and then 2.5 to $4.5 \mathrm{~h}$ for the small intestine). ${ }^{\mathrm{a}, \mathrm{b}}$ Means for each $\mathrm{pH}$ value without the same superscripts differ $(p<0.05)$. AGJ: Artificial gastric juice; AIJ: Artificial intestinal juice; DON: Deoxynivalenol (5 mg/kg); LiP: Lignin peroxidase (50 U/g). Data are expressed as mean $\pm \operatorname{SD}(n=3)$.

\section{Discussion}

Fusarium graminearum is not only a phytopathogenic fungus that induces Fusarium Head Blight (FHB) in grains but also produces a highly toxic molecule-DON [26]. There has been an increasing interest in searching for biological antifungal agents to replace synthetic pesticides in recent years. Among natural antifungal compounds, particular interests have been focused on the extracts of plant or agricultural by-products. Akyus and Kirbag [33] suggested that white rot fungi Pleurotus eryngii had antimicrobial activity. Schalchli et al. [34,35] also indicated that another species of white-rot fungi Trametes hirsuta was able to synthesize antifungal compounds. The current study found that both $\mathrm{MnP}$ and $\mathrm{LiP}$ treatments had antifungal abilities and $\mathrm{LiP}$ was found to be more effective than $\mathrm{MnP}$. The mixtures of $\mathrm{MnP}$ and $\mathrm{LiP}$ contained $\mathrm{H}_{2} \mathrm{O}_{2}$ and veratryl alcohol, respectively. It has been reported that veratryl alcohol had concentration-independent antifungal activity that could inhibit the growth of phytopathogenic fungi Sclerotinia sclerotiorum and Pythium irregular [36], but little information is available about the antifungal effects of $\mathrm{H}_{2} \mathrm{O}_{2}$. It is suggested that veratryl alcohol and the peroxidase from the SMS of F. velutipes in PDA are the major compounds responsible for the antifungal activity of the $\mathrm{LiP}$ treatment.

The fungal cell wall is comprised of glucan and chitin that play essential roles in several biological functions, such as cell shape, morphogenesis, reproduction, cell-matrix interactions, and physical osmotic protection [37]. The content of chitin is also critical for maintaining the physical strength of cell walls. Many studies have indicated that loss of chitin synthase activity in F. graminearum can significantly compromise fungal growth, development, and pathogenicity [38,39]. In the present study, the chitinase activity and GlcNAc content were both increased in $\mathrm{MnP}$ and LiP treatments compared to that in the control treatment. In addition, hyphal vesicles became visible inside the cell wall after $\mathrm{MnP}$ and LiP treatments, and the hyphae became broken down after LiP treatment (Figure 1). These results strongly suggest that $\mathrm{MnP}$ and LiP could enhance chitinase activity and cause degradation or degeneration of hyphae. Nevertheless, further studies are required to disclose the mechanisms behind it. 
It is known that white-rot fungi can produce extracellular ligninolytic peroxidases i.e., $\mathrm{MnP}$ and $\mathrm{LiP}$, which catalyze the formation of hydroxyl free radicals through oxidative reaction and thus alter the chemical bonds or molecular conformation of their substrates. These ligninolytic peroxidases have extremely low specificity for substrates. While MnP degrades lignin and phenolic compounds by oxidizing the substrate in the presence of $\mathrm{H}_{2} \mathrm{O}_{2}$ and $\mathrm{Mn}^{2+}$ [27], LiP degrades various xenobiotic compounds by oxidizing substrates that contain $\mathrm{H}_{2} \mathrm{O}_{2}$ and veratryl alcohol [27]. Moreover, these peroxidases are widely applied in the paper industry and environment protection [40], because they not only degrade lignin but also a wide range of environmental contaminants, such as phenols, polycyclic aromatic hydrocarbons, and aromatic water-pollutants [41]. Deoxynivalenol is a mycotoxin secreted during the secondary metabolism of $F$. graminearum, and is only produced by some fungus lineages [42]. As mentioned, both $\mathrm{MnP}$ and LiP treatments were found to inhibit the growth of hyphae and sporulation of F. graminearum KR1, which in turn, could minimize DON production after $\mathrm{MnP}$ and/or LiP treatments. Therefore, these two SMS-derived peroxidases from $F$. velutipes could potentially be used as biological antifungal agents although LiP appeared more effective than $\mathrm{MnP}$ in the present study.

Degradation of mycotoxins by ligninolytic enzymes purified from white-rot fungi has been intensively studied. The crude enzyme extract from SMS of P. eryngii [43] and MnP purify from Pleurotus ostreatus [44] can both effectively degrade up to $90 \%$ of $\mathrm{AFB}_{1}$. However, MnP has been verified as being capable of degrading DON effectively [30], but to our best knowledge, no report is available on the DON degradation capacity of LiP. In our preliminary test for DON degradation, the degradability of DON with $\mathrm{MnP}$ was $63.2 \%, 67.8 \%$, and $75.8 \%$ at $\mathrm{pH} 2.5,4.5$, and 6.5 , respectively; the best degradability was revealed between $\mathrm{pH} 4.5$ and 6.5. These results were in agreement with the previous studies, in which an optimal $\mathrm{pH}$ for MnP activity ranged from 4 to 6 [44,45]. For LiP, its best degradability of DON with $50 \mathrm{U} / \mathrm{mL}$ tryptone was $80.3 \%$ under $\mathrm{pH} 4.5$ in this study (Figure 3). This is also similar to that reported by S. Rodríguez Couto et al. [45], where the optimal $\mathrm{pH}$ was 4.2 at $34^{\circ} \mathrm{C}$ Unlike the effects of $\mathrm{pH}$ value and temperature, light might not directly affect the biological activities and stabilities of $\mathrm{MnP}$ and $\mathrm{LiP}$ but there has been no study to date.

In addition to $\mathrm{pH}$ value and temperature, small molecule mediators also play an essential role in the peroxidative functions of $\mathrm{MnP}$ and LiP. Hydrogen peroxidase and veratryl alcohol are important mediators for intensifying the antifungal reactions and DON degradability by $\mathrm{MnP}$ and LiP. In the presence of $\mathrm{H}_{2} \mathrm{O}_{2}, \mathrm{MnP}$ oxidizes the substrate faster than in other substrates without $\mathrm{H}_{2} \mathrm{O}_{2}$ [46]. In industrial applications, a high concentration of $\mathrm{H}_{2} \mathrm{O}_{2}$ in $\mathrm{MnP}$ solution is important to stabilize $\mathrm{MnP}$ activity [44]. Christian et al. [47] also indicated that veratryl alcohol enhances the oxidation of LiP on many compounds, including lignin, suggesting that veratryl alcohol acts as a redox mediator.

For our gastrointestinal simulations, DON degradabilities of LiP treatment at $50 \mathrm{U} / \mathrm{g}$ were $85.5 \%$ and $70.1 \%$, respectively. It was demonstrated that LiP can effectively degrade the nonphenolic derivative-DON in the gastrointestinal simulations of pig and poultry after incubation with feed mixtures for $4.5 \mathrm{~h}$ or longer. It is worth mentioning that $\mathrm{MnP}$ and LiP could be developed into antifungal agents and DON-degrading feed additives to avoid economic loss of crops. However, currently no study is available on the toxicity or cytotoxicity of $\mathrm{MnP}, \mathrm{LiP}$, as well as their metabolites after enzymatic digestion with regard to animals and humans. It has become extremely important to investigate their toxicity before applying these peroxidases as food or feed additives. Besides, the use of suitable carriers (e.g., yeast cell wall) to increase the stability of $\mathrm{MnP}$ and LiP during storage should also be carried out in the future. In addition to the potential applications of MnP and LiP, the present study has adequately provided a simplified purification procedure in turning disposed SMS into a valuable by-product from the mushroom industry in an environment-friendly manner. 


\section{Conclusions}

To our best knowledge, this is the first report on the ability of $\mathrm{MnP}$ and LiP to inhibit the growth of $F$. graminearum KR1 and the production of DON. The growth inhibition and the chitinase activity of $\mathrm{LiP}$ are more effective than that of $\mathrm{MnP}$. Also, effective degradation of DON by LiP treatment in simulated gastrointestinal systems was demonstrated in the present study. Therefore, $\mathrm{MnP}$ and LiP are potentially applicable as inhibitory enzymes to the growth and DON production of F. graminearum KR1, as well as to degrade existing DON in animal feeds, given that the toxicities of these peroxidases and the resulting metabolites are under strict surveillance. More studies are also required for future applications of $\mathrm{MnP}$ and $\mathrm{LiP}$ as anti-Fusarium or anti-DON feed additives in both food and animal industries.

\section{Materials and Methods}

\subsection{Chemicals and Fungal Strain}

Deoxynivalenol standard with purity higher than $99 \%$ was purchased from Fermentek (Jerusalem, Israel). Acetonitrile and methanol were high-performance liquid chromatography (HPLC) grade purchased from Merck (Darmstadt, Germany).

Acetic acid, bile salt, chitin, hydrogen peroxidase $\left(\mathrm{H}_{2} \mathrm{O}_{2}\right)$, manganese sulfate $\left(\mathrm{MnSO}_{4}\right)$, monopotassium phosphate $\left(\mathrm{KH}_{2} \mathrm{PO}_{4}\right)$, GlcNAc, $p$-dimethylamino benzaldehyde ( $p$-DMAB), polyethylene glycol (PEG, molecular weight 8000$)$, pepsin, potassium borate $\left(\mathrm{B}_{4} \mathrm{~K}_{3} \mathrm{O}_{3}\right)$, sodium acetate $\left(\mathrm{C}_{2} \mathrm{H}_{3} \mathrm{NaO}_{2}\right)$, trypsin, Tris- $\mathrm{HCl}$, and veratryl alcohol were purchased from Sigma-Aldrich (Saint Louis, USA).

Alfa Aesar (Haverhill, MA, USA) supplied 2,6-dimethyoxyphenol (2,6-DMP), tartaric acid, and potassium sodium L-tartrate tetrahydrate. The Czapek solution agar and potato dextrose agar (PDA) were purchased from BD Difco (Franklin Lakes, NJ, USA).

The commercial pig and poultry feed used in the in vitro procedure were provided by Farmwealth (Tainan, Taiwan). F. graminearum KR1, isolated from the wheat in Taiwan and maintained in PDA at $4{ }^{\circ} \mathrm{C}$, was provided by Dr. C. L. Wang, Department of Plant Pathology, National Chung Hsing University, Taichung, Taiwan.

\subsection{Extraction and Analyses of MnP and LiP}

The SMS of F. velutipes used to extract MnP and LiP were obtained from a mushroom farm (Dai Yang farm) in Wufeng district (Taichung, Taiwan). The substrate of $F$. velutipes consisting of sawdust, rice bran, wheat bran, and corn flour, was collected after the harvest of golden needle mushroom. The procedures for the extraction and analysis of $\mathrm{MnP}$ and LiP were based on previous studies [48-50], with some modifications. Briefly, to $120 \mathrm{~g}$ SMS of $F$. velutipes, $600 \mathrm{~mL}$ of $1 \mathrm{M}$ sodium acetate buffer $(\mathrm{pH} 3)$ and $0.25 \mathrm{M}$ tartaric acid buffer ( $\mathrm{pH}$ 4.5) were added for the extractions of $\mathrm{MnP}$ and LiP, respectively. After standing at room temperature for $24 \mathrm{~h}$, the enzymes were extracted as follows. Samples were centrifuged at $10,000 \times g$ for $10 \mathrm{~min}$ before the collection of supernatants through filter paper (Whatman\#1, Whatman, Maidstone, England). For MnP, the reaction mixture was $2.5 \mathrm{~mL}$ and consisted of $0.5 \mathrm{~mL}$ extracted MnP filtrate, $0.75 \mathrm{~mL}$ water, $0.5 \mathrm{~mL}$ of $5 \mathrm{mM}$ 2,6-DMP, $0.25 \mathrm{~mL}$ of $0.01 \mathrm{M} \mathrm{MnSO}_{4}, 0.25 \mathrm{~mL} 0.1 \mathrm{mM}$ of $\mathrm{H}_{2} \mathrm{O}_{2}$, and $0.25 \mathrm{~mL}$ of $0.1 \mathrm{M}$ sodium acetate buffer (pH 4.5) [48,49]. For $\mathrm{LiP}$, the reaction mixture was $2.5 \mathrm{~mL}$ and consisted of $0.75 \mathrm{~mL}$ water, $0.5 \mathrm{~mL}$ extracted LiP filtrate, $0.5 \mathrm{~mL}$ of $10 \mathrm{mM}$ veratryl alcohol, $0.25 \mathrm{~mL}$ of $0.5 \mathrm{M} \mathrm{H}_{2} \mathrm{O}_{2}$, and $0.25 \mathrm{~mL}$ of $0.25 \mathrm{M}$ tartrate buffer ( $\mathrm{pH} 3$ ) $[49,50]$. The reaction mixtures were placed in a glass cryotube, stored at $-20^{\circ} \mathrm{C}$ for freeze-dry preparation, and then connected to a freeze dryer (FD-12-2S-GP, Kingmech Co. New Taipei City, Taiwan) for freeze-drying based on the manufacturer's instruction. The dried powders of $\mathrm{MnP}$ and $\mathrm{LiP}$ were stored at $-20{ }^{\circ} \mathrm{C}$ until use.

The activities of $\mathrm{MnP}$ and $\mathrm{LiP}$ were evaluated using spectrometry (SmartSpec Plus, Bio-Rad, Hercules, CA, USA) at $469 \mathrm{~nm}$ and $310 \mathrm{~nm}$, respectively. For enzyme activities, 
extinction coefficients of $27500 \mathrm{M}^{-1} \mathrm{~cm}^{-1}$ for $\mathrm{MnP}$ and $9300 \mathrm{M}^{-1} \mathrm{~cm}^{-1}$ for LiP were used and estimated according to the following equations:

$$
\begin{gathered}
\text { Manganese peroxidase activity }(\mathrm{U} / \mathrm{mL})=\Delta A / \min \times 2.5 \times 10^{6} \times D / 27500 \mathrm{M}^{-1} \mathrm{~cm}^{-1} \\
\text { Lignin peroxidase activity }(\mathrm{U} / \mathrm{mL})=\Delta A / \min \times 2.5 \times 10^{6} \times D / 9300 \mathrm{M}^{-1} \mathrm{~cm}^{-1}
\end{gathered}
$$

where $\Delta A / \min =$ Increase in absorbance for $1 \mathrm{~min}$ at $469 \mathrm{~nm}$ for $\mathrm{MnP}$ or $310 \mathrm{~nm}$ for LiP

$D=$ Sample dilution

The calculated activities of $\mathrm{MnP}$ and LiP were respectively $67.8 \pm 8.1 \mathrm{U} / \mathrm{mL}$ and $1914 \pm 37 \mathrm{U} / \mathrm{mL}$ in the reaction mixtures, and $237 \pm 2.6 \mathrm{U} / \mathrm{g}$ and $2201 \pm 15.6 \mathrm{U} / \mathrm{g}$ in the powders. The experiment was carried out with three replicates per treatment.

\subsection{Antifungal Activity Assays}

The methods to determine antifungal activities of $\mathrm{MnP}$ and $\mathrm{LiP}$ were according to Cho et al. [51] In the control treatment, a $0.5 \mathrm{~cm}$ colony of $F$. graminearum KR1 was cultivated in PDA at $25^{\circ} \mathrm{C}$ in the dark for 7 days. In the treatment groups, the PDA was autoclaved $\left(121^{\circ} \mathrm{C}, 15 \mathrm{~min}\right)$ and cooled to approximately $50^{\circ} \mathrm{C}$. Then, MnP and LiP solutions were added into PDA with the concentration adjusted to $50 \mathrm{U} / \mathrm{mL}$. A $0.5 \mathrm{~cm}$ colony of $F$. graminearum KR1 was inoculated at the center of each PDA containing MnP and LiP at $25{ }^{\circ} \mathrm{C}$ in darkness for 7 days, and the growth of colonies was observed. Eight repeats of the experiment were conducted for each treatment group. For assessing the growth inhibition rate, the colony diameter was measured regularly by day. The growth inhibition rate of the mycelium was calculated as follows:

$$
\begin{aligned}
& \text { Growth inhibition rate }(\%)=(1 \text {-diameter of mycelium in the } M n P \text {-and LiP-treated } \\
& \text { medium/diameter of mycelium in the non-treated medium }) \times 100
\end{aligned}
$$

\subsection{Determination of GlcNAc Content, Chitinase Activity, and Hyphae Morphology}

The hyphal preparation, hyphal morphology observation, and analysis of GlcNAc content and chitinase activity were conducted according to methods described by Shi et al. [52]. Briefly, the F. graminearum KR1 pathogen was grown in PDA at $25^{\circ} \mathrm{C}$ for 7 days, and the $10 \mathrm{~mm}$ mycelium was inoculated into $500 \mathrm{~mL}$ flasks containing $250 \mathrm{~mL}$ of sterilized Czapek solution agar and cultured in flasks with $140 \mathrm{rpm}$ at $25^{\circ} \mathrm{C}$ for $72 \mathrm{~h}$. Then, MnP and $\mathrm{LiP}$ were added to a final concentration of $50 \mathrm{U} / \mathrm{mL}$ and the mycelium growth was observed 1, 3, 6, and $12 \mathrm{~h}$ after treatment. The effects of MnP and LiP on the hyphal morphology were observed using a light microscope (E100, Nikon, Tokyo, Japan). The hyphal materials ( $0.4 \mathrm{~g}$ dry weight) were harvested and homogenized in $2 \mathrm{~m} \mathrm{~L}$ of Tris- $\mathrm{HCl}$ $(0.05 \mathrm{M}, \mathrm{pH} 7.5)$. The homogenate was centrifuged at $15,000 \times \mathrm{g}$ for $10 \mathrm{~min}$ at $4{ }^{\circ} \mathrm{C}$, and the supernatant was used to determine GlcNAc content and chitinase activity. For determining GlcNAc content, $0.2 \mathrm{~mL}$ of supernatant liquid was treated with $0.1 \mathrm{~mL}$ of $0.8 \mathrm{M}$ potassium borate solution, and the mixture was placed in a boiling water bath for $3 \mathrm{~min}$. After cooling down, $3 \mathrm{~mL}$ of $1 \% p$-DMAB was added, and the samples were kept at $36^{\circ} \mathrm{C}$ for $20 \mathrm{~min}$, and then immediately analyzed by spectrophotometer at $544 \mathrm{~nm}$. For determining chitinase activity, gelatin form chitin ( $0.2 \mathrm{~mL}$ of $\mathrm{N}$-acetylation product of chitosan) was added to $0.3 \mathrm{~mL}$ of supernatant liquid, and the mixture was kept at $37^{\circ} \mathrm{C}$ for $1 \mathrm{~h}$ and inactivated in boiling water for $5 \mathrm{~min}$. After centrifugation at $5000 \times \mathrm{g}$ for $10 \mathrm{~min}, 0.2 \mathrm{~mL}$ of supernatant liquid was kept in a boiling water bath for $3 \mathrm{~min}$. After cooling down, $0.1 \mathrm{~mL}$ of $0.8 \mathrm{M}$ potassium borate solution and $3 \mathrm{~mL}$ of $1 \% p$-DMAB were added. After incubation at $36{ }^{\circ} \mathrm{C}$ for $20 \mathrm{~min}$, the sample was immediately analyzed by spectrophotometer at $544 \mathrm{~nm}$. Different GlcNAc concentrations were used to establish the standard curves for assessing GlcNAc content and chitinase activity. Three repeats were carried out in each treatment. 


\subsection{Preparation of Artificial Digestive Juices}

The AGJ and AIJ were prepared according to Tso et al. [53] and Wang et al. [15]. For the preparation of AGJ, sodium chloride ( $2 \mathrm{~g})$ and pepsin $(3.2 \mathrm{~g})$ were dissolved in sufficient water. Five $\mathrm{mL}$ of $36.5 \% \mathrm{HCl}$ was added into the solution and aliquoted to $1000 \mathrm{~mL}$ with water to obtain the AGJ followed by adjusting the $\mathrm{pH}$ values to 2.5 and 4.5 with $0.1 \mathrm{M}$ $\mathrm{NaOH}$. For the preparation of $\mathrm{AIJ}, \mathrm{KH}_{2} \mathrm{PO}_{4}(6.8 \mathrm{~g})$ was dissolved in $500 \mathrm{~mL}$ water, and the $\mathrm{pH}$ value was adjusted to 6.8 with $0.1 \mathrm{M} \mathrm{NaOH}$. Ten grams of trypsin were dissolved in water to mix with the $\mathrm{KH}_{2} \mathrm{PO}_{4}$ solution. Then, $3 \mathrm{~g}$ of porcine bile salt was added, aliquoted to $1000 \mathrm{~mL}$, and adjusted $\mathrm{pH} 6.5$ with $36.5 \% \mathrm{HCl}$. Both AGJ and AIJ were kept at $4{ }^{\circ} \mathrm{C}$ before use.

\subsection{A Pre-Test for DON Degradability of MnP and LiP}

DON standard solution was added to the feed for adjusting DON concentration to $0.5 \mathrm{mg} / \mathrm{kg}$. One hundred and eighty grams of poultry feed containing $0.5 \mathrm{mg} / \mathrm{kg}$ DON was premixed with $50 \mathrm{U} / \mathrm{g}$ of $\mathrm{MnP}$ and $\mathrm{LiP}$ powder, respectively. Sixty grams of peroxidasetreated feed was added to a $500 \mathrm{~mL}$ centrifuge tube and mixed with AGJ (pH 2.5 and then 4.5) or AIJ ( $\mathrm{pH}$ 6.5) at a 1:3 (w/v) ratio. The $\mathrm{pH}$ values of the resulting solutions were adjusted to $2.5,4.5$, or 6.5 with $36.5 \% \mathrm{HCl}$ or $0.1 \mathrm{M} \mathrm{NaOH}$ before incubating in a shaking incubator $(40.0 \pm 5 \mathrm{rpm})$ at $40.0 \pm 1{ }^{\circ} \mathrm{C}$ for $1 \mathrm{~h}$. From each treatment group, $20 \mathrm{~mL}$ of AGJ or AIJ mixture was collected and centrifuged with $5000 \times g$ for $10 \mathrm{~min}$ at $4{ }^{\circ} \mathrm{C}$; then $10 \mathrm{~mL}$ of centrifuged AGJ or AIJ supernatant was added to DON extraction solution for the analysis of residual DON concentrations. The experiment was carried out with three replicates per treatment.

\subsection{Simulations of Pig and Poultry Gastrointestinal Tracts with LiP Treatment}

Similar to the pre-test procedure, the simulation conditions for the gastrointestinal tracts of pig and poultry were based on the procedures reported in Tso et al. [53]. Different DON concentrations for pig $(1 \mathrm{mg} / \mathrm{kg})$ and poultry $(5 \mathrm{mg} / \mathrm{kg})$ feeds were used based on a report from the China Hygienic Standard for Feed (GB13078-2017) and FDA regulations [54]. The DON standard was added to the commercial pig and poultry feeds to adjust the desired DON concentration.

As described previously, $180 \mathrm{~g}$ of pig and poultry feeds, each with DON concentration of $0.5 \mathrm{mg} / \mathrm{kg}$ DON, were premixed with $\mathrm{LiP}$ powder $(50 \mathrm{U} / \mathrm{g})$. The mixture $(60 \mathrm{~g})$ was added to a $500 \mathrm{~mL}$ centrifuge tube to mix with AGJ at a $1: 3(w / v)$ ratio; the $\mathrm{pH}$ was then adjusted to target value and cultured in an incubator at $40{ }^{\circ} \mathrm{C}$ with constant shaking (40 rpm). Twenty $\mathrm{mL}$ of AGJ or AIJ mixtures was collected hourly and centrifuged for DON extraction. Similarly, $10 \mathrm{~mL}$ of centrifuged AGJ or AIJ supernatant was directly added to the DON extraction solution.

For the stimulation in the pig stomach, the pH 2.5 of AGJ was incubated for $5 \mathrm{~h}$. For the stimulated poultry crop and glandular stomach, the $\mathrm{pH} 4.5$ of AGJ was first incubated for $2 \mathrm{~h}$ and then the AGJ was adjusted to $\mathrm{pH} 2.5$ to mimic gizzard conditions (for $30 \mathrm{~min}$ ).

Before pig and poultry small intestine simulations, treatment mixtures were also centrifuged at $5000 \times g$ for $10 \mathrm{~min}\left(4^{\circ} \mathrm{C}\right)$ and filtered to remove AGJ; the residual feed (pellet) was stored under $-20^{\circ} \mathrm{C}$ for further determination. The samples of AGJ from each treatment were immediately extracted and analyzed to determine the DON concentrations and LiP activity. After this process, the DON standard was added to the feed samples in order to adjust DON concentration and LiP activity to the desired conditions of AGJ for the small intestinal simulations; thereafter, the AIJ was added $(1: 3, w / v)$ and the $\mathrm{pH}$ was adjusted (6.5) followed by a $2 \mathrm{~h}$-incubation to mimic the small intestine condition of pigs and poultry. The experiment was carried out with three replicates per treatment.

\subsection{DON Extraction and Assay}

The DON analysis was slightly modified according to methods described in Tso et al. [53]. For extracting DON from the solid samples (PDA and feed), $5 \mathrm{~g}$ of solid 
sample was mixed with $20 \mathrm{~mL}$ of DON extraction solution ( $1 \mathrm{~g}$ PEG $/ 20 \mathrm{~mL}$ water) in a $250 \mathrm{~mL}$ quartz cup. The mixture was blended by a homogenizer (PT-MR 3000, Brinkmann, Germany) at 40,000 rpm for $5 \mathrm{~min}$, and then was filtered through filter paper (Whatman\#1, Whatman, England) and a glass fiber filter (Vicam\#31955, Vicam, Milford, MA, USA). For extracting DON from the artificial digestive juices (AGJ and AIJ), $10 \mathrm{~mL}$ of artificial digestive juice was mixed with $10 \mathrm{~mL}$ of DON extraction solution $(1 \mathrm{~g}$ PEG/10 mL water) in a $50 \mathrm{~mL}$ centrifuge tube and then vortexed for $2 \mathrm{~min}$ (Vortex-Genie 2, Scientific Industries, Bohemia, NY, USA) before filtering through a glass microfiber filter. The procedures for DON purification and HPLC analysis were the same as for liquid samples.

For purifying DON, $2 \mathrm{~mL}$ of filtered extract was completely passed through the DONTest ${ }^{\mathrm{TM}}$ affinity column (Vicam, Milford, MA, USA). Subsequently, the affinity column was washed with $5 \mathrm{~mL}$ water, eluting the affinity column by passing $2 \mathrm{~mL}$ methanol through the column and collecting all the sample eluate in a glass cuvette. The eluate was dried by a nitrogen concentrator (Pierce React-Therm III ${ }^{\mathrm{TM}}$, Thermo Fisher Scientific, Waltham, MA, USA), resuspended in $2 \mathrm{~mL}$ acetonitrile-water $(10: 90, v / v)$, mixed well by vortexing, and then filtered with a syringe filter (pore size: $0.45 \mu \mathrm{m}$; Micron Separations, Westborough, MA, USA) for HPLC analysis. For analysis, $50 \mu \mathrm{L}$ of the filtered sample was injected into an HPLC pump (L-2130, Hitachi, Japan) by using an auto-sampler (L-2200, Hitachi, Tokyo, Japan) with the ultraviolet (UV) detector at $220 \mathrm{~nm}$. The mobile phase (acetonitrile-water, 10:90, $v / v$ ) was filtered through a $0.45 \mu \mathrm{m}$ filter membrane (Micron Separations, Westborough, MA, USA), degassed, and analyzed at the flow rate of $1 \mathrm{~mL} / \mathrm{min}$. The HPLC column used was a Mightysil ${ }^{\mathrm{TM}}$ RP-C18 column $(4.6 \times 250 \mathrm{~mm}, 5 \mu \mathrm{m}$, Kanto Chemical, Tokyo, Japan).

\subsection{Statistical Analysis}

All data in this study were analyzed with Analysis of Variance (ANOVA), and the General Linear Model (GLM) procedure in the PC-SAS ${ }^{\circledR}$ version 9.2 statistical software (SAS Institute, 2008) was used. Tukey's test was used to determine differences between individual means at a significance level $p<0.05$, unless otherwise stated. All the experimental data were expressed as mean $\pm \mathrm{SD}$.

Author Contributions: K.-H.T. carried out the research and wrote the draft. C.L. reviewed the draft. J.-C.J., Y.-K.F. and H.-IC. provided facilities, reviewed, and edited the draft. All authors have read and agreed to the published version of the manuscript.

Funding: This study is partially supported by a grant (\#DMR-108-128) from China Medical University Hospital, Taichung, Taiwan.

Institutional Review Board Statement: Not applicable.

Informed Consent Statement: Not applicable.

Data Availability Statement: Data available in a publicly accessible repository.

Acknowledgments: The authors are grateful to C. L. Wang, and C. Y. Cheng, Department of Plant Pathology, National Chung Hsing University, for fungal support and suggestions during the course of the study. We also wish to thank Dan C. Cliciu, Graduate Institute of Biomedical Sciences, China Medical University, for proofreading this manuscript.

Conflicts of Interest: The authors declare no conflict of interest.

\section{References}

1. Smith, M.C.; Madec, S.; Coton, E.; Hymery, N. Natural co-occurrence of mycotoxins in foods and feeds and their in vitro combined toxicological effects. Toxins (Basel) 2016, 8, 94. [CrossRef] [PubMed]

2. Eskola, M.; Kos, G.; Elliott, C.T.; Hajslova, J.; Mayar, S.; Krska, R. Worldwide contamination of food-crops with mycotoxins: Validity of the widely cited 'FAO estimate' of 25. Crit. Rev. Food Sci. Nutr. 2020, 60, 2773-2789. [CrossRef] [PubMed]

3. Li, Y.; Wang, Z.; Beier, R.C.; Shen, J.; De Smet, D.; De Saeger, S.; Zhang, S. T-2 toxin, a trichothecene mycotoxin: Review of toxicity, metabolism, and analytical methods. J. Agric. Food Chem. 2011, 59, 3441-3453. [CrossRef] [PubMed] 
4. Gardiner, D.M.; Osborne, S.; Kazan, K.; Manners, J.M. Low pH regulates the production of deoxynivalenol by Fusarium graminearum. Microbiol. Sgm. 2009, 155, 3149-3156. [CrossRef]

5. Magan, N.; Aldred, D.; Hope, R.; Mitchell, D. Environmental factors and interactions with mycobiota of grain and grapes: Effects on growth, deoxynivalenol and ochratoxin production by Fusarium culmorum and Aspergillus carbonarius. Toxins 2010, 2, 353-366. [CrossRef]

6. Schmidt-Heydt, M.; Parra, R.; Geisen, R.; Magan, N. Modelling the relationship between environmental factors, transcriptional genes and deoxynivalenol mycotoxin production by strains of two Fusarium species. J. R. Soc. Interface 2011, 8, 117-126. [CrossRef]

7. Moretti, A.; Pascale, M.; Logrieco, A.F. Mycotoxin risks under a climate change scenario in Europe. Trends Food Sci. Technol. 2019, 84, 38-40. [CrossRef]

8. Rocha, O.; Ansari, K.; Doohan, F.M. Effects of trichothecene mycotoxins on eukaryotic cells: A review. Food Addit. Contam. 2005, 22, 369-378. [CrossRef]

9. Springler, A.; Hessenberger, S.; Reisinger, N.; Kern, C.; Nagl, V.; Schatzmayr, G.; Mayer, E. Deoxynivalenol and its metabolite deepoxy-deoxynivalenol: Multi-parameter analysis for the evaluation of cytotoxicity and cellular effects. Mycotoxin Res. 2017, 33, 25-37. [CrossRef]

10. Awad, W.A.; Ghareeb, K.; Dadak, A.; Hess, M.; Bohm, J. Single and combined effects of deoxynivalenol mycotoxin and a microbial feed additive on lymphocyte DNA damage and oxidative stress in broiler chickens. PLoS ONE 2014, 9, e88028. [CrossRef]

11. European Commission. Commission Regulation (EC) No 1126/2007, on setting maximum levels for certain contaminants in foodstuffs as regards Fusarium toxins in maize and maize products. Off. J. Eur. Union 2007, 255, 14-17.

12. Agriopoulou, S.; Stamatelopoulou, E.; Varzakas, T. Advances in occurrence, importance, and mycotoxin control strategies: Prevention and detoxification in foods. Foods 2020, 9, 137. [CrossRef] [PubMed]

13. Bretz, M.; Beyer, M.; Cramer, B.; Knecht, A.; Humpf, H.U. Thermal degradation of the Fusarium mycotoxin deoxynivalenol. J. Agric. Food Chem. 2006, 54, 6445-6451. [CrossRef]

14. Doll, S.; Danicke, S. In vivo detoxification of Fusarium toxins. Arch. Anim. Nutr. 2004, 58, 419-441. [CrossRef] [PubMed]

15. Wang, R.G.; Su, X.O.; Fan, X.; Wang, P.L.; Gao, Z.W.; Zhang, Y. Liquid chromatography-tandem mass spectrometry for determination of aflatoxin $\mathrm{B}_{1}$, deoxynivalenol and zearalenone in artificial porcine gastrointestinal digestive juice. Chin. J. Anal. Chem. 2015, 43, 1-6. [CrossRef]

16. Kihal, A.; Rodriguez-Prado, M.; Godoy, C.; Cristofol, C.; Calsamiglia, S. In vitro assessment of the capacity of certain mycotoxin binders to adsorb some amino acids and water-soluble vitamins. J. Dairy Sci. 2020, 103, 3125-3132. [CrossRef]

17. Tomasevic-Canovic, M.; Dakovic, A.; Markovic, V.; Radosavljevic-Mihajlovic, A.; Vukicevic, J. Adsorpton effects of mineral adsorbents; Part III: Adsorption behaviour in the presence of vitamin $\mathrm{B}_{6}$ and microelements. Acta. Vet. Beogr. 2000, 50, $23-29$.

18. European Commission. Commission Regulation (EC) No 466/2001 of 8 March 2001 setting maximum levels for certain contaminants in foodstuffs. Off. J. Eur. Union 2001, 77, 1-13.

19. Al-Rashood, K.A.; Abdel-Aziz, H.A. Thiazolo[3,2-a]benzimidazoles: Synthetic strategies, chemical transformations and biological activities. Molecules 2010, 15, 3775-3815. [CrossRef]

20. Awad, W.A.; Ghareeb, K.; Bohm, J.; Zentek, J. Decontamination and detoxification strategies for the Fusarium mycotoxin deoxynivalenol in animal feed and the effectiveness of microbial biodegradation. Food Addit. Contam. Part A Chem. Anal. Control. Expo. Risk Assess. 2010, 27, 510-520. [CrossRef]

21. Young, J.C.; Zhou, T.; Yu, H.; Zhu, H.; Gong, J. Degradation of trichothecene mycotoxins by chicken intestinal microbes. Food Chem. Toxicol. 2007, 45, 136-143. [CrossRef] [PubMed]

22. Ikunaga, Y.; Sato, I.; Grond, S.; Numaziri, N.; Yoshida, S.; Yamaya, H.; Hiradate, S.; Hasegawa, M.; Toshima, H.; Koitabashi, M. Nocardioides sp. strain WSN05-2, isolated from a wheat field, degrades deoxynivalenol, producing the novel intermediate 3-epi-deoxynivalenol. Appl. Microbiol. Biotechnol. 2011, 89, 419-427. [CrossRef] [PubMed]

23. Ito, M.; Sato, I.; Ishizaka, M.; Yoshida, S.; Koitabashi, M.; Yoshida, S.; Tsushima, S. Bacterial cytochrome P450 system catabolizing the Fusarium toxin deoxynivalenol. Appl. Environ. Microbiol. 2013, 79, 1619-1628. [CrossRef] [PubMed]

24. Vanhoutte, I.; De Mets, L.; De Boevre, M.; Uka, V.; Di Mavungu, J.D.; De Saeger, S.; De Gelder, L.; Audenaert, K. Microbial Detoxification of deoxynivalenol (DON), assessed via a lemna minor L. bioassay, through biotransformation to 3-epi-DON and 3-epi-DOM-1. Toxins (Basel) 2017, 9, 63. [CrossRef] [PubMed]

25. Fuchs, E.; Binder, E.M.; Heidler, D.; Krska, R. Structural characterization of metabolites after the microbial degradation of type A trichothecenes by the bacterial strain BBSH 797. Food Addit. Contam. 2002, 19, 379-386. [CrossRef]

26. Karlovsky, P. Biological detoxification of the mycotoxin deoxynivalenol and its use in genetically engineered crops and feed additives. Appl. Microbiol. Biotechnol. 2011, 91, 491-504. [CrossRef]

27. Kumar, A.; Chandra, R. Ligninolytic enzymes and its mechanisms for degradation of lignocellulosic waste in environment. Heliyon 2020, 6, e03170. [CrossRef]

28. Hofrichter, M. Review: Lignin conversion by manganese peroxidase (MnP). Enzyme Microb. Technol. 2002, 30, 454-466. [CrossRef]

29. Wang, J.; Ogata, M.; Hirai, H.; Kawagishi, H. Detoxification of aflatoxin $B_{1}$ by manganese peroxidase from the white-rot fungus Phanerochaete sordida YK-624. FEMS. Microbiol. Lett. 2011, 314, 164-169. [CrossRef]

30. Wang, X.L.; Qin, X.; Hao, Z.Z.; Luo, H.Y.; Yao, B.; Su, X.Y. Degradation of four major mycotoxins by eight manganese peroxidases in presence of a dicarboxylic acid. Toxins 2019, 11, 566. [CrossRef] 
31. Garda-Buffon, J.; Kupski, L.; Badiale-Furlong, E. Deoxynivalenol (DON) degradation and peroxidase enzyme activity in submerged fermentation. Cienc. E. Tecnol. Alime. 2011, 31, 198-203. [CrossRef]

32. Feltrin, A.C.P.; Garcia, S.O.; Caldas, S.S.; Primel, E.G.; Badiale-Furlong, E.; Garda-Buffon, J. Characterization and application of the enzyme peroxidase to the degradation of the mycotoxin DON. J. Environ. Sci. Health B 2017, 52, 777-783. [CrossRef] [PubMed]

33. Akyuz, M.; Kirbag, S. Antimicrobial activity of Pleurotus eryngii var. ferulae grown on various agro-wastes. Eurasia J. Biosci. 2009, 10, 58-63. [CrossRef]

34. Schalchli, H.; Hormazabal, E.; Rubilar, O.; Briceno, G.; Mutis, A.; Zocolo, G.J.; Diez, M.C. Production of ligninolytic enzymes and some diffusible antifungal compounds by white-rot fungi using potato solid wastes as the sole nutrient source. J. Appl. Microbiol. 2017, 123, 886-895. [CrossRef]

35. Schalchli, H.; Hormazabal, E.; Becerra, J.; Briceno, G.; Hernandez, V.; Rubilar, O.; Diez, M.C. Volatiles from white-rot fungi for controlling plant pathogenic fungi. Chem. Ecol. 2015, 31, 754-763. [CrossRef]

36. Vinale, F.; Ghisalberti, E.L.; Flematti, G.; Marra, R.; Lorito, M.; Sivasithamparam, K. Secondary metabolites produced by a root-inhabiting sterile fungus antagonistic towards pathogenic fungi. Lett. Appl. Microbiol. 2010, 50, 380-385. [CrossRef]

37. Beauvais, A.; Latge, J.P. Special issue: Fungal cell wall. J. Fungi (Basel) 2018, 4, 91. [CrossRef]

38. Kim, J.E.; Lee, H.J.; Lee, J.; Kim, K.W.; Yun, S.H.; Shim, W.B.; Lee, Y.W. Gibberella zeae chitin synthase genes, GzCHS5 and GzCHS7, are required for hyphal growth, perithecia formation, and pathogenicity. Curr. Genet. 2009, 55, 449-459. [CrossRef]

39. Zhang, Y.Z.; Chen, Q.; Liu, C.H.; Liu, Y.B.; Yi, P.; Niu, K.X.; Wang, Y.Q.; Wang, A.Q.; Yu, H.Y.; Pu, Z.E. Chitin synthase gene FgCHS8 affects virulence and fungal cell wall sensitivity to environmental stress in Fusarium graminearum. Fungal Biol. 2016, 120, 764-774. [CrossRef]

40. Bansal, N.; Kanwar, S.S. Peroxidase(s) in environment protection. Sci. World J. 2013, 2013, 714639. [CrossRef]

41. Asgher, M.; Bhatti, H.N.; Ashraf, M.; Legge, R.L. Recent developments in biodegradation of industrial pollutants by white rot fungi and their enzyme system. Biodegradation 2008, 19, 771-783. [CrossRef] [PubMed]

42. Cambaza, E.; Koseki, S.; Kawamura, S. Fusarium graminearum colors and deoxynivalenol synthesis at different water activity. Foods 2018, 8, 7. [CrossRef] [PubMed]

43. Brana, M.T.; Sergio, L.; Haidukowski, M.; Logrieco, A.F.; Altomare, C. Degradation of aflatoxin $B_{1}$ by a sustainable enzymatic extract from spent mushroom substrate of Pleurotus eryngii. Toxins (Basel) 2020, 12, 49. [CrossRef] [PubMed]

44. Yehia, R.S. Aflatoxin detoxification by manganese peroxidase purified from Pleurotus ostreatus. Braz. J. Microbiol. 2014, 45, 127-133. [CrossRef] [PubMed]

45. Couto, S.R.; Moldes, D.; Sanromán, M.A. Optimum stability conditions of $\mathrm{pH}$ and temperature for ligninase and manganesedependent peroxidase from Phanerochaete chrysosporium. Application to in vitro decolorization of Poly R-478 by MnP. World J. Microb. Biot. 2006, 22, 607-612. [CrossRef]

46. Xu, H.; Guo, M.Y.; Gao, Y.H.; Bai, X.H.; Zhou, X.W. Expression and characteristics of manganese peroxidase from Ganoderma lucidum in Pichia pastoris and its application in the degradation of four dyes and phenol. BMC Biotechnol. 2017, 17, 19. [CrossRef] [PubMed]

47. Christian, V.; Shrivastava, R.; Shukla, D.; Modi, H.; Vyas, B.R.M. Mediator role of veratryl alcohol in the lignin peroxidasecatalyzed oxidative decolorization of Remazol Brilliant Blue R. Enzyme Microb. Technol. 2005, 36, 327-332. [CrossRef]

48. Leontievsky, A.A.; Myasoedova, N.M.; Baskunov, B.P.; Golovleva, L.A.; Bucke, C.; Evans, C.S. Transformation of 2,4,6trichlorophenol by free and immobilized fungal laccase. Appl. Microbiol. Biotechnol. 2001, 57, 85-91. [CrossRef]

49. De Souza, D.F.; Tychanowicz, G.K.; de Souza, C.G.; Peralta, R.M. Co-production of ligninolytic enzymes by Pleurotus pulmonarius on wheat bran solid state cultures. J. Basic Microbiol. 2006, 46, 126-134. [CrossRef]

50. Tychanowicz, G.K.; de Souza, D.F.; Souza, C.G.M.; Kadowaki, M.K.; Peralta, R.M. Copper improves the production of laccase by the white-rot fungus Pleurotus pulmonarius in solid state fermentation. Braz. Arch. Biol. Technol. 2006, 49, 699-704. [CrossRef]

51. Cho, J.S.; Seo, Y.C.; Yim, T.B.; Lee, H.Y. Effect of Nanoencapsulated vitamin $B_{1}$ derivative on inhibition of both mycelial growth and spore germination of Fusarium oxysporum f. sp. raphani. Int. J. Mol. Sci. 2013, 14, 4283-4297. [CrossRef] [PubMed]

52. Shi, Z.; Shen, S.; Zhou, W.; Wang, F.; Fan, Y. Fusarium graminearum growth inhibition due to glucose starvation caused by osthol. Int. J. Mol. Sci. 2008, 9, 371-382. [CrossRef] [PubMed]

53. Tso, K.H.; Ju, J.C.; Fan, Y.K.; Chiang, H.I. Enzyme degradation reagents effectively remove mycotoxins deoxynivalenol and zearalenone from pig and poultry artificial digestive juices. Toxins (Basel) 2019, 11, 599. [CrossRef] [PubMed]

54. Park, D.L.; Troxell, T.C. US perspective on mycotoxin regulatory issues. Mycotoxins Food Saf. 2002, 504, $277-285$. 